\title{
PSIKOLOGI TRANSPERSONAL; \\ Mengenal Konsep Kebahagiaan dalam Psikologi
}

\section{Oleh Abu Bakar MS}

Abstrak: Kehadiran psikologi transpersonal memberikan arti yang cukup penting dalam menjawab problem-problem kemanusiaan masa kini dan juga dalam upaya menafsirkan serta mengevaluasi gejala-gejala keagamaan secara psikologis. Psikologi transpersonal menempatkan agama dalam susunan pengalaman manusia yang bersifat pribadi, yang memiliki akar dalam kehidupan psikis. Oleh karena itu, gejala agama bukanlah sekadar luapan konflik dan ketegangan di saat masa kanak-kanak yang tidak terpecahkan, akan tetapi agama merupakan wujud transendensi diri dengan kekuatannya sendiri. Agama bagi seseorang, dalam pandangan psikologi transpersonal, merupakan urusan pribadinya dengan Tuhan. Di sisi lain, tasawuf Islam tetap mengakui adanya aspek metafisika yang menjadi bahan telaah psikologi transpersonal. Sehingga, kebahagiaan dalam psikologi ini, adalah aktualisasi dari penghambaan kepada Tuhan.

Kata Kunci: Psikologi, Kebahagiaan, Islam 
PSIKOLOGI TRANSPERSONAL;

Mengenal Konsep Kebahagiaan dalam Psikologi

\section{Oleh Abu Bakar MS}

\section{Pengantar}

Masyarakat modern, saat ini, mengalami apa yang sebut sebagai gejala Dysthymia, yang berarti sebuah perasaan sedih yang kronis dan hilangnya energi kehidupan di tengahtengah kehidupan sukses dan tampak bahagia. ${ }^{1}$

Gejala lain yang dapat ditangkap dari kehidupan modern adalah apa yang disebut oleh para psikolog dengan istilah anxiety disorder. Seorang penderita gejala ini biasanya memiliki ciri-ciri berikut ini: seringkali terganggu dengan detak jantungnya, gampang terangsang dan tersiksa oeh gangguan yang kecil, memiliki ketakutan tiba-tiba tanpa alasan yang jelas, cemas dan putus asa secara terus menerus, merasa sangat lelah dan kehabisan tenaga, sulit mengambil keputusan, takut pada segala hal, merasa nervous dan tegang terus-menerus, tidak dapat mengatasi kesulitan yang dihadapinya, dan tertekan. Bersamaan dengan itu, penderita gejala ini juga mengalami gangguan fisik seperti kesulitan kosentrasi, keluar keringat dingin, tidak bisa tidur, kelelahan, sesak nafas, kepala pusing, dan sebagainya. ${ }^{2}$

1 Jalaluddin Rakhmat, Meraih Kebahagiaan, (Bandung: Simbiosa Rekatama Media, 2008), hlm. 25

2 Jalaluddin Rakhmat., Catatan Kang Jalal: Visi Media, Politik, dan Pendidikan, (Bandung: Rosda Karya, 1996), hlm. 261 
Menurut Bastaman, fenomena di atas merupakan sebuah gambaran yang boleh jadi merepresentasikan sisi suram dari manusia yang hidup di abad ke-21 yang biasa disebut dengan Abad Kecemasan (The Age of Anxiety). Dikatakan demikian, karena abad ini banyak ditandai oleh adanya krisis multi dimensi; ekonomi, politik, sosial, budaya dan lingkungan, yang melanda dan menimbulkan efek psikologis (kecemasan) pada seluruh masyarakat dunia. Semua krisis tersebut sejatinya berakar dari krisis identitas yang bersumber dari tidak jelasnya jati diri sebagai pribadi dan bangsa. Krisis identitas dan hilangnya jati diri dalam tatanan psikis berkaitan erat dengan tidak jelasnya nilai-nilai yang dapat dijadikan pedoman hidup. Akibatnya, banyak manusia mengalami penderitaan, karena gagal dalam menggapai kehidupan yang bemakna dan berbahagia. ${ }^{3}$

Dalam bahasa Sayyed Hossein Nasr, manusia modern dikatakan tengah mengalami apa yang disebut dengan kehampaan spiritual, krisis makna, kehilangan legitimasi hidup, dan mengalami keterasingan (alienasi) terhadap dirinya sendiri. Krisis eksistensial ini bermula dari pemberontakan manusia modern terhadap Tuhan. Mereka telah kehilangan harapan akan kebahagiaan masa depan sebagaimana dijanjikan oleh renaisans, abad pencerahan, sekulerisme, saintisme, dan teknologisme. ${ }^{4}$

Dengan kata lain, manusia modern di abad ke-21 ini dapat dikatakan telah kehilangan visi spiritualnya. Ia memerlukan insight baru agar dapat menemukan kembali visi spiritualnya. Psikologi kontemporer (Barat) dapat dikatakan telah "gagal" menjawab persoalan manusia modern tersebut. Psikologi, dalam pandangan Seligman, seorang mantan Ketua Asosiasi Psikologi Amerika (APA), pada dasarnya merupakan ilmu

3 Bastaman H. D, Integrasi Psikologi dengan Islam, Menuju Psikologi Islami, (Yogyakarta, Pustaka Pelajar, 1995), hlm. 56 atau Bastaman, H.D, Logoterapi: Psikologi untuk Menemukan Makna Hidup dan Meraih Hidup Bermakna, (Jakarta: Rajawali Pers, 2007), hlm. 48

${ }^{4}$ Haidar Bagir, Buku Saku Filsafat Islam, (Bandung: Mizan, 2006), hlm. 75 
yang mempelajari tentang manusia dari segala sudut pandang. Ironisnya, pada 60 tahun terakhir ini psikologi hanya berorientasi pada penyakit jiwa seperti phobia, stress, trauma, skizofrenia dan masih banyak lagi penyakit kejiwaan lainnya. Menurutnya, selama 60 tahun terakhir ini, kajian tentang berbagai penyakit (gangguan) psikologis menyimpulkan bahwa ada 14 macam penyakit yang berhasil diobati, tetapi tidak sembuh total, dan terdapat dua macam penyakit lainnya dapat diobati secara total. Fakta ini kemudian menimbulkan pertanyaan: "bagaimana caranya membuat orang menjadi sehat tanpa terhindar dari penyakit atau gangguan mental?". Dari pertanyaan inilah kemudian istilah Psikologi Positif (Psikologi Kebahagiaan) itu muncul. Oleh karena itu, dengan perspektif Psikologi transformatif, penulis akan menguraikan makna bahagia.

\section{Makna Bahagia}

Persoalan kebahagiaan telah lama menjadi tema pembahasan para sastrawan, agamawan, dan para filosof. Dalam Kamus Besar Bahasa Indonesia kata bahagia dan derivasinya dijelaskan secara teperinci. Kata "bahagia", dalam bentuk kata benda, diartikan sebagai keadaan atau perasaan senang dan tenteram, serta bebas dari segala yang menyusahkan. Makna ini dapat dipahami dari ungkapan "bahagia dunia akhirat" atau "hidup penuh bahagia". Dalam bentuk kata benda lainnya, kebahagiaan, diartikan sebagai kesenangan, ketenteraman hidup (lahir batin), keberuntungan, dan kemujuran yang bersifat lahir dan batin. Hal ini dapat dipahami dari kalimat "Kehadiran bayi itu mendatangkan kebahagiaan di rumah tangganya" atau "Saling pengertian antara suami-isteri akan membawa kebahagiaan di rumah tangga".

Dalam bentuk kata sifat, berbahagia dapat iartikan sebagai beruntung. Hal ini dapat dipahami dari kalimat "Saya betul-betul merasa berbahagia, karena dapat berada kembali di tengah-tengah keluarga". Dalam bentuk kata kerja, kata membahagiakan berarti menjadikan atau membuat bahagia. Makna ini dapat dilihat dari kalimat "Ia berusaha keras membahagiakan 
keluarganya". Dapat pula diartikan sebagai "mendatangkan rasa bahagia", jika dilihat dari kalimat: "Kehadirannya sangat membahagiakan keluarganya". Di luar itu, kata bahagia dapat pula dikaitkan dengan kata "selamat", misalnya dengan kata-kata "selamat berbahagia". Kata bahagia dalam ungkapan ini berarti sejahtera atau sehat. Jika dikaitkan dengan kata taman ("taman bahagia"), maka dapat berarti "tempat orang mendapat kebahagiaan". ${ }^{5}$

Di luar bahasa Indonesia, kata bahagia dapat dijumpai dalam berbagai bahasa seperti Inggris (Happiness), Jerman (Gluck), Latin (Felicitas), Yunani (Eutychia, Eudaimonia), dan Arab (Falah, Sa'adah). Kata ini menunjukkan arti sebagai berikut: kebahagiaan, keberuntungan, kesenangan, peluang baik, dan kejadian yang baik. Dalam bahasa Cina (Xing Fu), kebahagiaan terdiri dari gabungan kata "beruntung" dan "nasib baik". Setiap orang, dengan berbagai tingkatan usia dan latar belakang, memiliki gambaran yang berbedabeda tentang kebahagiaan. ${ }^{6}$ Jika ada sepuluh anak ditanya tentang apa itu kebahagiaan?, maka jawabannya boleh jadi akan sangat berbeda-beda. Ada yang mengidentikkan orang bahagia dengan orang yang tinggal di rumah besar dan mewah, mobil mengkilap, pakaian yang indah, makanan yang lezat, memiliki isteri yang cantik, memiliki tubuh yang indah, dan ebagainya. Ada pula yang menggambarkan kebahagiaan dengan sebuah ungkapan menarik yang cukup populer di kalangan kaum remaja dewasa ini, yaitu : "selagi muda foya-foya, tua kaya- raya, mati masuk sorga".

Para filosof sendiri berbeda pendapat dalam mendefinisikan kebahagiaan. Ada yang menggambarkan sebagaimana anak-anak di atas dan ada pula yang melihat kebahagiaan jauh di atas itu. Menurut Aristoteles, manusia mampu melihat kebahagiaan jauh di atas kesenangan-kesenangan fisik. Sebagian filosof lain, misalnya kaum Hedonis dan Utilitarian, menetapkan kebahagiaan sebagai landasan moral. Baik buruknya suatu tindakan diukur sejauh mana tindakan itu membawa orang pada kebahagiaan (lebih tepatnya kesenangan). Ada pula filosof yangmengatakan bahwa perbuatan baik dan buruk tidak berkaitan sama sekali dengan

${ }^{5}$ Kamus Besar Bahasa Indonesia dalam Maktabah Al-Kubra: Media Pembelajaran dan literatur Islam Digital, Ver. 5

${ }^{6}$ Jalaluddin Rakhmat, Meraih.......hlm. 31 
kebahagiaan, karena boleh jadi ada tindakan yang membuat pelakunya bahagia (senang), tetapi tidak bermoral, misalnya korupsi. Menurut kelompok ini, perbuatan baik adalah tuntutan etis untuk menjalankan kewajiban, walaupun membuat pelakunya menderita.

Bahkan, ada pula filosof yang menyatakan bahwa bahagia adalah sesuatu yang tidak jelas (tidak ada batasnya). Bahagia dianggap khayalan belaka yang tidak rasiona. Bukan hal yang aneh jika banyak orang ingin bahagia, tetapi tidak mengetahui batasan bahagia itu sendiri, tidak tahu apa yang sebenarnya ia cari dalam hidup ini, atau mereka bingung ke mana dan bagaimana mencari kebahagiaan. Mereka terpesona dengan masa yang telah lewat. Mereka ingin kebahagiaan masa lalu hadir kembali, sebagaimana yang pernah mereka rasakan bersama orangtua atau keluarga mereka dulu.

Sementara dunia yang mereka hadapi saat ini tampak semakin suram, banyak masalah, penuh krisis, dan tidak menentu. Seolah mereka ingin lari dari realitas bahwa dalam hidup ini banyak kesulitan, permasalahan, dan beban yang semakin berat. ${ }^{8}$

Demikianlah sebagian makna kebahagiaan yang telah dirumuskan para filosof (sufi) yang boleh jadi masih berupa konsep yang abstrak. Untuk itu, tugas para psikolog adalah bagaimana mengkongkritkan hal yang abstrak ini. Jika ada seorang klien datang ke psikolog dan berkata: "Hari ini saya merasa bahagia", maka sang psikolog tentu akan bertanya lebih lanjut: "Mengapa anda merasa bahagia?". Salah satu jawaban yang mungkin akan diberikan seseorang adalah: "Karena saya merasa puas dengan apa yang terjadi dengan hidup saya".

Demikian halnya dengan kehidupan seseorang, apakah bermakna atau tidak dapat dinilai dari model pertanyaan dan jawaban di atas. Dialog di atas mengindikasikan bahwa kebahagiaan hidup seseorang dapat dinilai secara obyektif (objective happiness) dan subyektif (subjective happiness).

\footnotetext{
${ }^{7}$ Ibid, hlm. 46
}

${ }^{8}$ Ahmad Khalid Allam, dkk. Al-Qur'an dalam Keseimbangan Alam dan Kehidupan, terj. Oleh Abd. Rohim Mukti, (Jakarta: Gema Insani, 2005), hlm. 182

${ }^{9}$ Jalaluddin Rakhmat, Meraih......hlm. 4 
Secara obyektif, kebahagiaan seseorang dapat diukur dengan menggunakan standar yang merujuk pada aturan agama atau pembuktian tertentu. Jalaluddin Rakhmat mencontohkan, misalnya ada seseorang bernama Fulan. Ia menghabiskan waktu mudanya untuk berfoya-foya, termasuk dengan melakukan segala tindakan dosa. Ia tidak pernah mengalami sakit. Ia mengaku sangat bahagia. Benarkah ia bahagia? Menurut ukuran agama, ia dianggap tidak bahagia, karena pada hari akhirat kelak, jika ia tidak segera bertaubat, akan masuk neraka. Dalam bahasa Tasawuf, si Fulan ini dikatakan sedang mengalami apa yang disebut dengan istidraj. Artinya ia sedang diberi ujian oleh Allah dengan nikmat (kesenangan) untuk melihat apakah ia sadar atau tidak dengan nikmat yang didapatkannya. Menurut ukuran (pembuktian) rasional, ia juga tidak bahagia, karena lamakelamaan ia pasti akan kehilangan harta, kesehatan, dan kesenangannya. Secara subyektif, kita dapat mengukur kebahagiaan seseorang dengan bertanya kepadanya dengan singkat apakah ia bahagia atau tidak. ${ }^{10}$

Pada dasarnya, setiap orang selalu mendambakan kebahagiaan dalam hidupnya. Akan tetapi, kebahagiaan ini tidak akan terjadi begitu saja, namun merupakan akibat sampingan dari keberhasilannya dalam memenuhi keinginannya untuk hidup bermakna (will to meaning). Artinya, makna hidup adalah gerbang menuju kebahagiaan. Mereka yang berhasil mencapainya akan mengalami hidupyang bermakna dan dirinya akan memperoleh kebahagiaan. Sebaliknya mereka yang tidak berhasil memenuhi motivasi ini akan mengalami kekecewaan, kehampaan hidup, merasakan hidup yang tidak bermakna, dan akhirnya tidak bahagia. ${ }^{11}$

Gangguan atau karakter kepribadian yang mungkin dimiliki seseorang tergantung pada mampu (berhasil) atau tidaknya ia dalam menghayati hidupnya. Ketidakberhasilan menemukan makna hidup biasanya akan menimbulkan penghayatan hidup tanpa makna (meaningless), hampa, gersang, bosan, dan merasa tidak berarti. Jika hal ini berlarut-larut akan mengakibatkan gangguan neurosis (noogenic neurosis) serta mengembangkan karakter totaliter dan konformis.

\footnotetext{
${ }^{10} \mathrm{Ibid}$

${ }^{11}$ Bastaman (2007), Logoterapi.....,hal. 67
} 
Berkaitan dengan penghayatan hidup tanpa makna ini, seorang Logoterapis akan berpandangan bahwa kurang berfungsinya naluri dan intuisi, serta memudarnya nilai tradisi dan agama pada orang-orang modern merupakan faktor yang mendorong terjadinya hal itu. ${ }^{12}$

\section{Mengenal Psikologi Tranpersonal}

Pada awal hingga pertengahan abad ke-20, teori-teori psikologi Barat yaitu Psikologi Klinis dan Psikologi Eksperimen sangat mendominasi dan menjadi dasar untuk praktik dan penelitian. Namun kemudian beberapa peneliti menemukan bahwa ada pengalamanpengalaman dalam hidup manusia yang dapat merubah perspektif dan tujuan hidup seseorang secara signifikan. Para ahli humanistik percaya bahwa pengalaman-pengalaman manusia yang transformasional ini sangat krusial bagi kehidupan dan kesejahteraan, dan tidak dapat diukur dengan metode pengukuran baku.

Belakangan, muncul psikologi transpersonal yang secara khusus bertitik tolak pada kajian empiris terhadap fenomena perkembangan jiwa manusia yang menghasilkan teori-teori spesifik, antara lain: meta-need, nilai-nilai puncak, unitive consciousness, pengalaman puncak, b-values, pengalaman mistik, aktualisasi diri, transendensi diri, esensi kesatuan wujud, dan lain-lain. Pada intinya, psikologi ini ingi memahami manusia sebagai sesuatu yang bersifat alamiah, bersifat ketuhanan, supranatural, dan berbagai kategori lainnya. ${ }^{13}$

Aliran ini secara tidak langsung telah meng-counter aliran sebelumnya yang cenderung menafikan hal-hal yang bersifat supra natural dan adikodrati. Selanjutnya, aliran ini juga menjadi wacana baru dalam dunia psikologi. Munculnya psikologi transpersonal berawal dari kesadaran para psikolog akan problem-problem kemanusiaan yang diakibatkan oleh kemajuan ilmu pengetahuan dan teknologi dan juga kehancuran peradaban, serta hal-hal lain yang belum terjawab oleh teoriteori sebelumnya. Spiritualitas sebagai pengalaman dasar kemanusiaan

${ }^{12}$ Ajit K Das (1998), "Frankl and the Realm of Meaning", Journal of Humanistic Education and Development. Falls Church: Jun 1998. Vol. 36

${ }^{13}$ Charles T. Tart, Transpersonal Psychology (London: Harper and Row, 1975), 2. 
dalam hubungannya dengan hal-hal seperti Tuhan, ketinggian kodrat, cinta, tujuan dan idealitas, secara nyata gagal diurai oleh rasionalitas yang tercerahkan (enlightened rationalism) yang telah sukses dalam pengembangan sains dan teknologi (physical science), namun gagal dalam menyelesaikan problem-problem psikologis. Kegagalan pengetahuan dan teknologi dalam mengurai persoalan kemanusiaan saat ini bukan berarti menunjukkan ketidakmampuannya menjangkau problem kemanusiaan yang ada, namun karena pendekatan yang digunakan tidak dapat menjangkau persoalan tersebut. Kehadiran psikologi transpersonal yang juga disebut psikologi spiritual diharapkan bisa menjadi jembatan yang menghubungkan antara rasionalitas ilmu pengetahuan dengan pengalaman spiritual manusia. Bahkan kajian ilmu ini sendiri adalah bertitik tolak dari kekayaan pengalaman spiritual manusia.

Dengan demikian, psikologi transpersonal menjadi penghubung psikologi dan spiritualitas. Psikologi transpersonal mengintegrasikan konsep psikologi, teori, dan metode dengan materi dan praktik dari disiplin rohani subjek. Kepentingannya termasuk pengalaman spiritual, keadaan mistis sadar, kesadaran dan meditasi, shamanic states, ritual, overlap pengalaman spiritual dengan keadaan terganggu seperti psikosis dan depresi, dan dimensi transpersonal dari hubungan interpersonal, service, dan pertemuan dengan alam. ${ }^{14}$

Daniel berpendapat bahwa psikologi transpersonal adalah suatu cabang psikologi yang memberi perhatian pada studi terhadap keadaan dan proses pengalaman manusia yang lebih dalam dan luas, atau suatu sensasi yang lebih besar dari koneksitas terhadap orang lain dan alam semesta, atau merupakan dimensi spiritual. ${ }^{15}$ Boorstein mendefinisikan transpersonal sebagai pengalaman identitas diri yang melewati individu atau pribadi untuk mencakup aspek yang lebih luas dari kemanusiaan,

14 J. Davis, We keep asking ourselves, what is transpersonal psychology? Dalam Guidance \& Counseling, 15(3), 2000, hlm. 3-8

15 Sebagaimana dikemukakan oleh Prabowo, Pengantar Psikologi Transpersonal: Seri latihan kesadaran 1 . Diunduh dari: http://staff.undip. ac.id/psikologi/zaenal_abidin/files/201 0/07/1.-Pengantar-PsikologiTranspersonal.pdf. 2008) 
kehidupan, jiwa dan kosmos. ${ }^{16}$ Pendekatan transpersonal dapat didefinisikan sebagai pencapaian fungsi hidup, jiwa, dan kosmos dengan kesadaran dan pengalaman religius, menggunakan bermacam metode (konvensional dan tradisional).

Asumsi dasar yang dimiliki oleh pendekatan transpersonal adalah bahwa manusia adalah makhluk yang kompleks, gangguan-gangguan yang dapat diderita manusia sangat multi dimensional, dan perkembangan ilmu terlalu beragam, sehingga tidak mungkin hanya menggunakan hanya satu strategi. Terapis-terapis transpersonal mencari jalan yang terbaik dari perpaduan teknik-teknik mainstream dengan perspektif transpersonal yang bertujuan untuk mencocokkan dengan kebutuhan klien. Perbedaan utama antara pendekatan transpersonal dengan pendekatan-pendekatan konvensional adalah terapi dilihat dari konteks spiritual dan transformasi, dan menggunakan praktikpraktik spiritual misalnya meditasi.

\section{Bahagia dalam Psikologi Transpersonal}

Seseorang itu merasa bahagia dengan sempurna karena ia secara utuh memiliki yang baik dan sempurna. Kebahagiaan sempurna itu datang dan sepenuhnya memuaskan segala keinginan kita, sedangkan kebahagiaan disebut tidak sempurna apabila tidak memuaskan semua keinginan kita atau, andaikata dapat memuaskan semua keinginan, tetapi tidaklah memuaskan keinginan dengan sepenuhnya. Guna menghindari kekacauan, hendaknya diperhatikan dengan sungguh-sungguh di sini bahwa filsafat moral memandang kebahagiaan kodrati saja (natural happiness). Kebahagiaan kodrati adalah pemuasan segala hasrat yang termasuk dan muncul dari kodrat telanjang manusia (man's bare nature).

Aristoteles berpendapat bahwa kebahagiaan bukanlah suatu perolehan untuk manusia dan corak bahagia itu lain-lain dari berbagai ragam, menurut corak dan ragam orang yang mencarinya. Kadang-kadang sesuatu yang dipandang bahagia oleh seseorang, tidak demikian oleh

${ }^{16}$ Sebagaimana yang sebut oleh Firman, Transpersonal psychology: An introduction to psychosynthesis. Diunduh dari: http:// synthesiscenter.org/PDF/Psychosynthe sisFirman.pdf. 
orang lain, sebab kebahagian merupakan suatu kesenangan yang dicapai oleh setiap orang menurut kehendak masing-masing. Ia juga berpendapat bahwa bahagia itu bukan mempunyai arti dari satu kejadian, melainkan berlainan coraknya menurut tujuan masing-masing manusia. Bahagia adalah tujuan akhir tiap-tiap manusia. ${ }^{17}$

Pendapat Aristoteles ini akan semakin beda apabila dipadukan dengan pendapat Hendrik Ibsen, ${ }^{18}$ yang secara mendasar ia frustasi dan kecewa dengan realitas bahagia ini. Hendrik berpendapat bhawa mencari bahagia itu hanya menghabiskan umur, karena jalan untuk menempuhnya sangat tertutup. Setiap usaha untuk melangkah ke sana senantiasa memperoleh kecewa, karena mulamula orang yang menujunya menyangka bahwa perjalanan telah dekat, tetapi secara nyata sangat jauh. Menurutnya, manusia belum pernah mencapai bahagia sebab setiap jalan yang ditempuh menjauhkan jalan manusia kepadanya.

Pendapat Hendrik Ibsen ini kontraproduktif dengan Leo Tolsyoy, ${ }^{19}$ secara mendasar ia berargumen bahwa yang menjadi sebab manusia putus asa di dalam mencari bahagia ialah karena bahagia itu diambilnya untuk dirinya sendiri bukan untuk bersama. Padahal segala bahagia yang diborong untuk sendiri itu mustahil berhasil karena bahagia semacam itu selalu mengganggu kebahagiaan orang lain. Orang lain yang terganggu akhirnya responsif jika ia tersinggung dan berusaha mempertahankan diri oleh sebab itu bukan lagi menuntut bahagia memberi keuntungan, tetapi

${ }^{17}$ Kajian tentang pemikiran Aristoteles bisa dilihat dalam Diane Colline, Lima Puluh Filosof Dunia Yang Menggerakkan, (Jakarta: Raja Grafindo Persada, 2001), Ali Mudhofir, Kamus Filsafat Barat, (Yogyakarta: Pustaka Pelajar, 2001) dan Ahmad Syadali, Filsafat Umum Untuk Fakultas Tarbiyah dan Ushuluddin Komponen MKDK, (Bandung: Pustaka Setia, 1997)

18 Wacana Hendrick Igsen lebih lanjut lihat Ahmad Tafsir, Filsafat Umum; Akal dan Hati Sejak Thales Sampai Capra, (Bandung: Remaja Rosdakarya, 2001), hlm. 145

19 Harry Hamesma, Tokoh-tokoh Filsafat Barat Modern, (Jakarta: Gramedia Pustaka Utama, 1992), hlm. 30 
memberi kerugian bersama, pendapat Tolstoy ini mendapat pengakuan dari Bertrand Russe ${ }^{20}$ dan George Bernard Snaw. ${ }^{21}$

Berangkat ari makna bahwa psikologi transpersonal lebih menitikberatkan pada dimensi transendental, maka kebahagiaan merupakan bagian dari pengalaman keagamaan yang dilakukan hanya atas dasar formalitas dan rutinitas belaka. Model kebahagiaan diperoleh melalui kegiatan-kegiatan yang jauh dari formalitas dan rutinitas.

Sebagaimana diketahui, dimensi ketuhanan (al-rûh al-illahîyah) merupakan sumber kekuatan pribadi manusia. Jika seseorang konsisten untuk mengaktualisir asma Allah atau dengan kata lain al-takhalluq bi asmâ' Allâh (mengambil nama-nama Allah sebagai sumber inspirasi segala perilakunya), ia akan meraih kesempurnaan yang didambakan. Takhalluq, menurut Ibn 'Arabî, adalah jalan spiritual menuju Allah yang melahirkan akhlak mulia sesuai dengan kehendak-Nya. Dengan takhalluq berarti mengukuhkan pandangannya bahwa tidak ada suatu realitaspun yang wujud kecuali Allah, nama-nama-Nya dan perbuatanperbuatan$\mathrm{Nya}^{22}$

Dalam tradisi tasawuf, banyak teori yang menyebut karakterkarakter keluhuran yang seharusnya dimiliki oleh manusia. Karakterkarakter tersebut tergambar dalam konsep-konsep sufistik seperti, maqâmât (stations), ahl wâl (states), ittihâd (unity), wahdat al-wujûd (kesatuan wujud), wahdat al-shuhûd (kesatuan penyaksian), wahdat al-adyân (kesatuan agamaagama), dan lain-lain. Menurut hemat penulis, konsepkonsep sufistik tersebut memiliki titik relevansi dengan konsep process of becoming dalam disiplin psikologi transpersonal. Sebagai contoh, maqâmât dalam tasawuf

${ }^{20}$ Ahmad Hanafi, Ikhtisar Sejarah Filsafat Barat, (Jakarta: Pustaka al-Husna, 1981), hlm. 98

${ }^{21}$ Harun Hadiwiyono, Sari Sejarah Filsafat Barat 2, (Yogyakarta: Kanisius, 1988), hlm. 120

${ }^{22}$ Muhy al-Dîn Ibn Arabî, al-Futuh ât al-Makkîyah, Vol. 3 (Mesir: Dâr al-Kutub al_Arabîyah, 1997), hlm. 68. Pada bagian lain diungkapkan bahwa ketika manusia menafikan wujudnya, ia kembali kepada sifat aslinya yakni ketiadaan', tetapi pada saat yang sama ia berada pada kondisi spiritual yang disebut Ibn 'Arabî sebagai -kebahagiaan yang abadill 
pada dasarnya merupakan rangkaian proses yang harus dijalani oleh seorang sâlik dalam perjalanan spiritualnya menuju Allah. Keberhasilan seorang sâlik dalam menjalani prosesproses tersebut pada akhirnya akan menjadikannya sebagai individu —yang menjadi individu yang paripurna karena dia telah - menjad kekasih dari Sang Maha Kasih.

\section{Bahagia dalam Psikologi Islam}

Setiap manusia pasti menginginkan dan mengharapkan memiliki jiwa yang bahagia, tenang, tentram dan jauh ketegangan-ketegangan serta konflik-konflik batin atau kejiwaan. Untuk mendapatkannya maka setiap manusia perlu memperhatikan faktor-faktor yang mendukung terciptanya jiwa yang tenang dan tentram. Faktor-faktor yang mendukung untuk tercapainya ketenteraman jiwa, dapat dilihat dari dua pendekatan, yaitu pendekatan psikologi dan pendekatan agama.

Dari pendekatan psikologi, ada beberapa factor yang mendukung terciptanya ketenteraman jiwa bagi manusia. Menurut Abraham Maslow sebagaimana dikutip oleh Jamaluddin Ancok bahwa "apabila manusia tidak dapat memenuhi kebutuhan hidupnya, maka ia akan mengalami gangguan jiwa". 23

Kebutuhan-kebutuhan hidup yang dimaksud adalah sebagai berikut: Pertama, Kebutuhan Fisiologis. Kebutuhan ini adalah kebutuhan dasar yang harus dipenuhi oleh setiap manusia untuk hidup; makan, minum, istirahat adalah contohcontoh dari kebutuhan dasar ini. Orang tidak akan memikirkan kebutuhan lainnya sebelum kebutuhan dasar ini terpenuhi.

Kedua, Kebutuhan akan Rasa Aman. Setelah orang dapat memenuhi kebutuhan dasar selanjutnya berkembang keinginan untuk memperoleh rasa aman. Orang ingin bebas dari rasa takut dan kecemasan. Manifestasi dari kebutuhan ini antara lain perlunya tempat tinggal yang permanent, pekerjaan yang permanen.

23 Jamaluddin Ancok, Psikologi Islami Solusi Islam atas Problem-Problem Psikologi, (Yogyakarta: Pustaka Pelajar, 1995), hlm. 92 
Ketiga, Kebutuhan Akan Rasa Kasih Sayang. Perasaan memiliki dan dimiliki oleh orang lain atau oleh kelompok masyarakat adalah Sesuatu yang dibutuhkan oleh setiap manusia. Kebutuhan akan terpenuhi bila ada saling perhatian, saling kunjung mengunjungi sesama anggota masyarakat. Keintiman di dalam pergaulan hidup sesame anggota masayarakat adalah sesuatu yang menyuburkan terpenuhinya kebutuhan ini.

Keempat, Kebutuhan Akan Harga Diri. Pada tingkat ini orang ingin dihargai sebagai manusia, sebagai warga Negara.

Kelima, Kebutuhan Akan Aktualisasi Diri. Kebutuhan pada tingkat ini adalah kebutuhan yang paling tinggi, menurut Maslow, pada tingkatan ini manusia ingin berbuat sesuatu yang semata-mata karena dia ingin berbuat sesuatu yang merupakan keinginan dari dalam dirinya. Dia tidak lagi menuntut penghargaan orang lain atas apa yang diperbuatnya. Sesuatu yang ingin dia kejar di dalam kehidupan. Tingkat ini antara lain adalah keindahan, kesempurnaan, keadilan dan kebermaknaan. ${ }^{24}$

Sedang menurut Kartini Kartono menyebutkan bahwa kebutuhankebutuhan hidup manusia meliputi: Pertama, Tercapainya kebutuhankebutuhan pokok. Dalam hal ini karena setiap manusia pasti memiliki dorongan-dorongan akan kebutuhan pokok. Dorongan-dorongan akan kebutuhan pokok tersebut menuntut pemenuhan, sehingga jiwa menjadi tentram atau boleh dikatakan bahwa ketegangan-ketegangan jiwa menjadi tentram, atau boleh dikatakan bahwa ketegangan-ketegangan jiwa akan menurun jika kebutuhankebutuhan pokok tersebut terpenuhi.

Kedua, Tercapainya kepuasan, sikap orang pasti menginginkan kepuasan, baik fisik maupun psikis. Dia ingin merasa kenyang, aman, terlindungi, ingin puas dalam hubungan seks nya, ingin mendapat simpati dan lain-lain, pendeknya ingin puas di segala bidang.

${ }^{24}$ Ibid, hlm. 92-93 
Ketiga, Posisi dan status sosial, setip lingkungannya, selama posisi dan status sosial itu sesuai dengan harapan san kemampuan dirinya, maka individu tersebut tidak mempunyai jiwa yang bimbang. ${ }^{25}$

Dari dua pendapat di atas dapat dipahami bahwa orang yang merasa sejahtera dan tentram jiwanya adalah apabila orang tersebut mampu memahami kebutuhan-kebutuhan hidupnya, baik yang bersifat fisik seperti sandang, pagan, papan dan kebutuhan psikis seperti rasa aman, rasa ingin tahu, rasa bebas merdeka, mencapai kesuksesan, dan memperoleh keadilan, serta kebutuhan sosial seperti kebutuhan memperoleh kasih sayang, kebutuhan dihargai atau memperoleh penghargaan. Sedang dalam pendekatan agama, manusia akan mempunyai jiwa yang tentram apabila manusia tersebut mempunyai iman yang kuat, teguh dan benar serta selalu mengingat kepada Allah. Seseorang yang keimanan nya telah menguasainya apapun yang terjadi tidak mengganggu dan mempengaruhinya. Dan dia merasa yakin bahwa keimanan nya itu akan membawanya kepada ketenteraman dan kelegaan hatinya. ${ }^{26}$

Hal ini diperkuat dengan statement yang difirmankan oleh Allah bahwa:

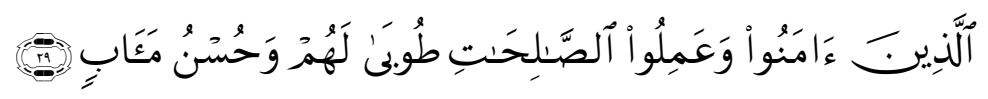

Artinya: "Orang-orang yang beriman dan beramal shaleh, kebahagiaan hiduplah bagi mereka dan tempat kembali yang baik". (Q.S. Al-Ra'du: 29).

Sebaliknya, bagi orang yang merasa hidupnya tidak bahagia, tidak tenang, selalu gelisah dan was-was, pasti mempunyai faktor-faktor yang menyebabkan nya, faktor-faktor penyebab tidak tenteram nya jiwa ini

${ }^{25}$ Kartini Kartono dan Jenny Andari, Hygiene, Mental dan Kesehatan Mental dalam Islam, (Bandung: Mandar Maju, 1989), hlm. 29 - 30.

${ }^{26}$ Zakiyah Daradjat, Islam dan Kesehatan Mental, (Jakarta: Gunung Agung, 1982), hlm. 1 
karena kebutuhan-kebutuhan pokok hidupnya tidak terpenuhi, kebutuhan fisik, psikis, dan kebutuhan-kebutuhan sosialnya.

Para psikolog sepakat bahwa ada dua faktor yang sangat mempengaruhi terjadinya ketidaksehatan jiwa atau mental, yaitu faktor penyedia (predisposing factor) dan faktor pencetus (participating factor). ${ }^{27}$ Faktor penyedia adalah faktor yang terkondisi dalam diri individu tetapi faktor ini bersifat pasif, sedangkan faktor pencetus adalah faktor incidental yang menggugah faktor penyedia menjadi aktif. Namun secara umum sumber utama dari hadirnya kelainan jiwa menurut pendekatan psikoanalisa ialah pengalaman pahit semasa kanak-kanak terutama kurangnya mendapat kasih sayang, kurang pengertian dan perhatian atau perasaan disia-siakan. Pengalaman-pengalaman pahit itu ditekan ke alam bawah sadar dan suatu saat muncul ke permukaan (predisposing factor).

Sedang dilihat dari kacamata agama, menurut Drs. Abdul Wahib karena adanya nafsu yang tidak dirahmati. Nafsu inilah yang menyeret seseorang untuk berbuat jahat dan salah sehingga hatinya tidak tentram, kemudian hati yang tidak tentram ini melahirkan perilaku yang menyimpang. ${ }^{28}$

Orang yang merasa banyak dosa, biasanya pikirannya selalu dikejarkejar oleh perasaan bersalah, kalau orang tersebut tidak cepatcepat ber taubat, maka perasaan bersalah tersebut bisa menimbulkan keteganganketegangan batin, sehingga jiwanya menjadi tidak tentram, demikian pula perasaan kecewa terhadap masa lalu, kalau hal ini tidak secepatnya dihilangkan, maka akan bisa mengakibatkan gangguan kejiwaan yang kurang menyenangkan atau tidak baik. Contohnya adalah timbulnya perasaan trauma terhadap suatu masalah yang pernah mengakibatkan dan menimbulkan sikap pesimis, minder, takut, dan sikapsikap lain yang sejenis yang kesemuanya dapat menjadikan jiwa tidak tenang dan tidak tentram. Dengan demikian jelaslah bahwa dari kacamata agama tingkat

${ }^{27}$ Abdul Wahib, Puasa dan Kesehatan Mental, dalam Media, Edisi, 10 th. 11/ Maret 1992, Fakultas Tarbiyah IAIN Walisongo Semarang, hlm. 57

${ }^{28}$ Ibid., hlm. 57-48 
keimanan seseorang akan membawa kepada ketenangan hatinya dan ketenteraman jiwanya.

\section{Penutup}

Kebahagiaan adalah motif terdasar dari segala sesuatu yang kita kerjakan. Setiap perbuatan kita digerakkan oleh keinginan. Pemuasan keinginan tersebut dituju atau dikehendaki paling sedikit sebagai suatu unsur dalam keseluruhan kebahagiaan kita. Sering kita harus mengorbankan beberapa hal yang baik untuk hal-hal yang baik lainnya. Bisa juga kita keliru memilih sesuatu yang nampaknya baik, dan tidak memilih sesuatu yang sebenarnya baik. Bisa juga kita, seperti orang yang tidak sehat akalnya, memilih suatu kesenangan yang sementara sifatnya pada saat sekarang ini dari pada memilih kebahagiaan yang lebih besar di hari nanti. Tetapi semua ini kita kerjakan untuk kebahagiaan.

Ini hanya menunjukkan bahwa kita bukannya tidak menghendaki kebahagiaan, tetapi justru menunjukkan bahwa kita sangat menghendaki kebahagiaan tersebut, sehingga kita tidak dapat menanti lebih lama lagi. Maka kita berusaha cepat-cepat merenggut bentuk-bentuk potongannya, bentuk tidak sempurnanya yang memikat demikian hebat terhadap panca indera kita.

Tidak perlulah kita dengan secara eksplisit memikirkan tentang kebahagiaan dalam segala hal yang kita kerjakan. Kita tidak perlu lebih dulu berhenti pada setiap perbuatan dan berkata kepada diri kita sendiri, "ini saya kerjakan supaya saya bahagia". Kadang-kadang, bila kita merenungkan tentang maksud hidup, kita bisa secara eksplisit membuat dan memerintah perbuatan-perbuatan kita selanjutnya, tetapi juga mereka yang tidak pernah memikirkan tentang arti dan maksud hidup, tetap berbuat secara implisit demi kebahagiaan.

Sejak zaman dahulu sampai sekarang, kebahagiaan itu selalu didamba dan dicari oleh setiap insan. Rupanya terlalu sulit untuk mendapatkannya bahkan untuk menentukan apa yang dimaksud dengan bahagia itu yang dalam bahasa Arab disebut as sa'adah, dalam bahasa Inggris disebut happiness, tidaklah mudah. Tiap orang mungkin mempunyai batasan sendiri, sehingga sukar menentukannya secara pasti. 
Berbagai kontradiksi tampak dalam kenyataan sehari-hari, misalnya ada pendapat yang mengatakan bahwa harta kekayaan membawa seseorang kepada kebahagiaan, namun sebaliknya sering terjadi, justru harta itu yang menghilangkan kebahagiaan.

Tidak jarang kita menemukan orang yang ketika dalam kemiskinan hidupnya tampak tenang, tidak cekcok dengan keluarga, hidupnya rukun, baik dalam rumah tangga maupun dengan tetangga, saudara, kerabat dan teman-temannya. Tetapi setelah rizkinya bertambah, fasilitas hidup semakin cukup bahkan melebihi kebutuhan, ketenangan mulai sirna dari keluarganya, suami istri mulai cekcok, kerukunan dalam pergaulan hilang berganti dengan salah paham, kurang serasi, yang menjurus ke suasana berantakan. Jadi kekayaan itu tidak dapat dijadikan ukuran untuk mencapai kebahagiaan. Artinya harta dapat membantu orang untuk mencapai kebahagiaan, tetapi harta juga dapat mendatangkan kesengsaraan dan kepedihan hidup. Dengan sendirinya tentu ada syarat lain yang memungkinkan agar harta itu dapat membawa kita kepada hidup bahagia.

\section{Daftar Pustaka}

Arabî, Muh\}y al-Dîn Ibn. al-Futuh ât al-Makkîyah, Vol. 3. Mesir: Dâr alKutub al-_Arabîyah, 1997.

Budiharjo, Paulus. Mengenal Teori Kepribadian Mutakhir. Yogyakarta: Kanisius, 1997.

Crapps, Robert W. Dialog Psikologi dan Agama. Yogyakarta: Kanisius, 1993.

Fromm, Erich. The Art of Living. New York: Harper and Row, 1956.

James, William. The Varieties of Religious Experiences. t.t.: The New American Library, 1958.

Maslow, Abraham H. The Farther Reaches of Human Nature. Canada: Penguin Books, 1971. 
Mohamed, Yasien. Insan yang Suci: Konsep Fitrah dalam Islam. Bandung: Mizan, 1995.

Muhammad, Hasyim. - Maqamat dan Ahwal dalam Tradisi Tasawuf dan

Psikologi Humanistik Abraham H. Maslow II . Tesis-IAIN Walisongo Semarang, 2000.

Firman, D. (2011). Transpersonal psychology: An introduction to psychosynthesis. Diunduh dari: http:// synthesiscenter.org/PDF/Psychosynthe sis-Firman.pdf.

Freeman, A. (2006). A Daniel Come To Judgement? Dennett and the Revisioning of Transpersonal Theory. Journal of Consciousness Studies, 13(3), 95-109.

Rowan, J. (2009). Transpersonal and Integral in Psychotherapy. Journal of Transpersonal Research, 1(1), 65-76.

Rowan, J. (2005) The transpersonal: Spirituality in psychotherapy and counselling (2nd edition). London: Routledge

Rowan, J. (1993). The Transpersonal: Psychotherapy and Counselling. London: Routledge. Walsh, R., \& Vaughan, F. (Eds.). (1993). Paths beyond ego: The transpersonal vision. New York: Jeremy P. Tarcher/ Putnam

Abu Bakar MS adalah Dosen pada Fakultas Psikologi Universitas Islam Negeri Sultan Syarif Kasim Riau.E-mail: abubakarms@uin-suska.ac.id 